\title{
EFEK FARMAKOLOGI DAN TOKSIK SIRSAK (Annona muricata): $A$ MINI-REVIEW
}

\section{PHARMACOLOGICAL AND TOXIC EFFECTS OF SOURSOP (AnnONa muricata): A MINI-REVIEW}

\section{Putu Nita Cahyawati}

Departemen Farmakologi dan Farmasi, Fakultas Kedokteran dan Ilmu Kesehatan, Universitas Warmadewa

Korespondensi: Putu Nita Cahyawati. Email: putunitacahyawati@gmail.com

\begin{abstract}
ABSTRAK
Annona muricata (sirsak) telah digunakan secara tradisional sejak lama untuk mengatasi demam, nyeri, gangguan pernapasan dan kulit, sebagai antiparasit, mengatasi infeksi bakteri, menurunkan tekanan darah, mengatasi peradangan, mengatasi diabetes dan kanker. Oleh karenanya, banyak studi baik in vitro maupun in vivo ditujukan untuk membuktikan manfaat tersebut. Senyawa kimia telah berhasil diisolasi dari tanaman ini diantaranya: alkaloid, fenol, dan asetogenin. Senyawa-senyawa tersebut diyakini berperan terhadap efek farmakologi pada berbagai kondisi penyakit. Walaupun demikian, keamanan atau toksisitas tanaman ini masih dipertanyakan baik untuk pemakaian jangka pendek maupun jangka panjang. Dosis efektif tanaman ini juga belum diketahui secara pasti. Melalui tulisan ini, penulis hendak merangkum berbagai efek farmakologi serta efek toksik yang dapat ditimbulkan oleh Annona muricata berdasarkan hasil penelitian terdahulu.
\end{abstract}

Kata Kunci: Annona Muricata, Sirsak, Efek Farmakologi, Efek Toksik

\section{ABSTRACT}

Annona muricata (sirsak) has been used traditionally for a long time to treated fever, pain, respiratory and skin disorders, as an antiparasitic, to treat bacterial infections, reduce blood pressure, to treat inflammation, diabetes and cancer. Therefore, many studies both in vitro and in vivo were aimed to prove these benefits. Various chemical compounds have been successfully isolated from these plants. These compounds were believed to play a vital role in pharmacological effects in various diseases. Nevertheless, the safety or toxicity of this plant was still questionable for both short and long term use. The effective dose of this plant was also not known with certainty. Through this paper, the author wishes to summarize the various pharmacological and toxic effects that can be caused by Annona muricata based on the results of previous studies.

Keywords: Annona Muricata, Soursop, Pharmacological Effects, Toxic Effects

How To Cite: Cahyawati, P. (2020). EFEK FARMAKOLOGI DAN TOKSIK SIRSAK (Annona muricata): A MINI-REVIEW. Biomedika, 12(2), 107-116. doi:https://doi.org/10.23917/biomedika.v12i2.10691

DOI: https://doi.org/10.23917/ biomedika.v12i2.10691 


\section{PENDAHULUAN}

Annona muricata (A. muricata) atau sirsak atau durian belanda dikenal dengan istilah yang berbeda-beda di berbagai tempat. $A$. muricata dikenal sebagai soursop di Inggris, graviola di Portugis, dan guanábana di Spanyol dan Amerika Latin. Pohon ini memiliki tinggi sekitar 5-10 $\mathrm{m}$ dan diameter $15-83 \mathrm{~cm}$ dengan cabang rendah (Coria-Téllez et al., 2018). Pohon ini banyak tumbuh di daerah tropis maupun subtropis (Moghadamtousi et al., 2015).

Penelitian secara in vitro melaporkan bahwa $A$. muricata memiliki efek antimikroba, antiinflamasi, anti protozoa, antioksidan, insektisida, larvisida, dan sitotoksik pada sel tumor. Sedangkan, studi in vivo membuktikan bahwa tanaman ini memiliki aktivitas anxiolitik, anti-stres, anti-inflamasi, kontrasepsi, antitumor, anti-ulkus, penyembuhan luka, hepatoprotektor, anti-ikterik dan hipoglikemik (CoriaTéllez et al., 2018; Gavamukulya et al., 2017).

Selama ini, pemanfaatan secara tradisional tanaman ini bertujuan untuk mengobati beragam kondisi seperti demam, nyeri, gangguan pernapasan dan kulit, antiparasit, infeksi bakteri, hipertensi, peradangan, diabetes dan kanker(Coria-Téllez et al., 2018).
Tulisan ini bertujuan untuk mengkaji dan menganalisis manfaat yang dimiliki oleh $A$. muricata berdasarkan hasil-hasil penelitian sebelumnya.

\section{METODE}

Studi in vitro dan studi preklinik pada hewan yang menilai efek farmakologi $A$. muricata dimasukkan pada kajian ini. Pencarian data dilakukan melalui mesin pencarian data PubMed dengan menggunakan kata kunci: Annona muricata atau A. muricata atau soursop atau graviola yang spesifik terdapat pada bagian judul atau abstrak.

Pada pencarian awal 311 artikel ditemukan. Penambahan kata kunci: efek toksik dan efek farmakologi menyisakan 40 artikel untuk dinilai lebih lanjut. Tahun publikasi artikel dibatasi yaitu 10 tahun terakhir. Setelah dilakukan penilaian terhadap kesesuaian bahasan pada telaah ini, 30 artikel akhirnya dipilih dan digunakan sebagai referensi.

\section{HASIL DAN DISKUSI Efek Antikanker}

Studi literatur dari beberapa penelitian menemukan bahwa lebih dari 200 senyawa kimia telah diidentifikasi dan diisolasi dari tanaman ini. Senyawa yang paling penting adalah alkaloid, fenol, dan asetogenin (Coria- 
Téllez et al., 2018; Gavamukulya et al., 2017; Roduan et al., 2019). Total fenol yang ditemukan dalam ekstrak air adalah $683,69 \pm 0,09$ $\mu \mathrm{g} / \mathrm{mL}$ gallic acid equivalents (GAE), sedangkan dalam ekstrak etanol sebesar $372,92 \pm 0,15 \mu \mathrm{g} / \mathrm{mL}$ GAE. Skrining fitokimia juga menemukan bahwa tanaman ini kaya akan senyawa metabolit kelas dua seperti, saponin, terpenoid, flavonoid, kumarin dan lakton, antrakuinon, tanin, glikosida jantung, dan pitosterol (Gavamukulya et al., 2014). Tanin gallics, tanin catechics, flavonoid, leucoanthocyans dan mucilage terdapat pada daun A. muricata. Namun, turunan kuinonik dan sianogenik serta saponosida tidak terdeteksi (Gbaguidi et al., 2017).

Komponen bioaktif utama yang diekstraksi dari berbagai bagian A. muricata adalah asetogenin. Ini adalah turunan dari asam lemak rantai panjang (C32 atau C34) yang berasal dari jalur poliketid. Asetogenin memiliki kemampuannya menginduksi sitotoksisitas, dengan menghambat kompleks mitokondria I, yang terlibat dalam reaksi oksidatif fosforilasi dan sintesis adenosine triphosphate (ATP). Kemampuannya sebagai inhibitor kompleks mitokondria I memunjukkan bahwa $A$. muricata memang memiliki memiliki potensi sebagai antikanker (Liaw et al., 2016; Rady et al., 2018). Pada studi in vitro daun $A$. muricata dilaporkan memiliki aktivitas antioksidan halfmaximal inhibitory concentration $\left(\mathrm{IC}_{50}\right)$ sebesar 2,0456 $\mathrm{mg} / \mathrm{mL}$ (ekstrak etanol) dan 0,9077 $\mathrm{mg} / \mathrm{mL}$ (ekstrak air). Ekstrak etanol juga menujukkan sifat selektif sitotoksik pada sel tumor (ehrlich ascites carcinoma cell (EACC), malondialdehyde (MDA) dan SKBR3) dengan nilai $\mathrm{IC}_{50}$ berturut-turut sebesar $335,85 \mu \mathrm{g} / \mathrm{mL}$, $248,77 \mu \mathrm{g} / \mathrm{mL}$, dan $202,73 \mu \mathrm{g} / \mathrm{mL}$, serta tidak memiliki efek sitotoksik pada sel limpa normal (Gavamukulya et al., 2014). Efek antikanker lainnya juga ditunjukkan dari hasil pengujian senyawa annonacin yang berasal dari daun $A$. muricata. Annonacin menunjukkan aktivitas sitotoksik yang luar biasa dengan $\mathrm{IC}_{50} 2,9 \pm 1,3$ $\mu \mathrm{M}$ (Roduan et al., 2019). Tanaman ini juga mampu memicu penghentian siklus sel, apoptosis, dan nekrosis, serta dapat menghambat pergerakan sel kanker, migrasi, metastasis, dan proliferasinya (Rady et al., 2018; Moghadamtousi et al., 2014).

Mekanisme penghambatan ini didapat melalui kemampuannya dalam memodulasi beberapa komponen proses seluler seperti penghambatan jalur sinyal epidermal growth 
factor receptor (EGFR), serta menghambat jalur sinyal phosphatidylinositol-4,5-bifosfat 3-kinase (PI3K/Akt), renin-angitensin system (RAS), nuclear factor kappa B (NF-кB), dan janus kinase/signal transducers and activators of transcription (JAK/STAT) (Rady et al., 2018; Moghadamtousi et al., 2014). Studi lain melaporkan bahwa ekstrak buah A. muricata secara signifikan menurunkan regulasi gen EGFR dan menghambat pertumbuhan sel kanker payudara dan xenografts dengan cara menurunkan ekspresi mRNA EGFR secara signifikan, menghentikan siklus sel dalam fase G0/G1, dan menginduksi apoptosis (Dai et al., 2011).

Kemampuan lain yang dimiliki $A$. muricata yaitu penghambatan hypoxia-inducible factor 1-alpha (HIF-1 $\alpha$ ), glucose transporter (GLUT1 dan GLUT4), enzim glikolitik (the glycolytic enzymes hexokinase II (HKII), lactate dehydrogenase $A$ (LDHA)) yang seluruhnya mengurangi pemakaian glokosa dan mengurangi produksi ATP pada sel kanker; ekspresi sitokin proinflamasi dan pembentukan reactive oxygen species (ROS) melalui peningkatan aktivasi sistem enzim katalase, superoksida dismutase (SOD), heme-oksigenase (HO-1), meningkatan sitokrom c, upregulasi Bax, downregulasi Bcl-2 dan menghambat ekspresi NADPH oxidase (NOX) (Rady et al., 2018; Moghadamtousi et al., 2014; Torres et al., 2012; Deep et al., 2016). Ekstrak metanol daun A. muricata menunjukkan aktivitas antioksidan tertinggi dari semua bahan uji dan menunjukkan kemampuan free radical scavenger yang paling kuat yaitu sebesar 87\% (Roduan et al., 2019). Berdasarkan data penelitian tersebut dapat disimpulkan bahwa A. muricata adalah agen antioksidan dan antikanker baru yang cukup menjanjikan (Gavamukulya et al., 2014).

\section{Efek Hipoglikemi dan Hipolipidemia}

Ekstrak A. muricata dilaporkan dapat menurunkan kadar glukosa darah dan low density lipoprotein (LDL) serta meningkatkan kadar high density lipoprotein (HDL) pada tikus jantan dan betina. Efek hipoglikemi dan hipolipidemia ini timbul pada dosis rendah. Kemampuan menurunkan kadar glukosa plasma dan efek positif dalam mencegah peningkatan faktor risiko kardiovaskular mengindikasikan bahwa ekstrak tersebut memiliki aktivitas antidiabetik yang baik (Arthur et al., 2011). Studi pada tikus hiperkolesterolemia menunjukkan bahwa pemberian ekstrak buah ini pada dosis $3,6 \mathrm{mg} / 200 \mathrm{gBB} /$ hari selama 14 hari 
mampu menurunkan kadar LDL (Fatimah dkk., 2019).

Hasil ini juga didukung oleh penelitian lainnya yang menyebutkan bahwa senyawa bioaktif pada tanaman ini memiliki aktivitas anti-hiperglikemik melalui beberapa mekanisme seperti merangsang sekresi insulin, meningkatkan perbaikan atau proliferasi sel $\beta$ dan meningkatkan efek insulin dan adrenalin. Kenaikan berat badan pada tikus diabetes melitus yang mendapatkan $100 \mathrm{mg} / \mathrm{kg}$ ekstrak $A$. muricata juga dilaporkan meningkat secara signifikan. Hasil ini kemungkinan disebabkan oleh kemampuannya dalam mengontrol kadar glikemik di dalam darah (Florence et al., 2014). Penelitian terbaru melaporkan bahwa ekstrak daun A. muricata secara signifikan menurunkan kadar LDL, meningkatkan kadar HDL dan toleransi glukosa pada dosis $150 \mathrm{mg} / \mathrm{kg}$. Ekstrak ini juga mampu menurunkan kadar very low density lipoprotein (VLDL) dan area adiposit pada jaringan adiposit epididimal pada dosis 100 mg/ kg dan $150 \mathrm{mg} / \mathrm{kg}$ (Sasso et al., 2019).

Potensi anti-diabetes ekstrak tanaman ini kemungkinan diperoleh melalui penghambataan pada aktivitas $\alpha$-amilase dan aktivitas $\alpha$-glukosidase. Penemuan ini mengindikasikan bahwa, A. muricata bisa sangat bermanfaat untuk perawatan dan manajemen hiperglikemia, diabetes, kelebihan berat badan, dan obesitas (Agu et al., 2019).

\section{Efek Analgetik}

Nyeri adalah pengalaman emosional dan sensorik yang tidak menyenangkan akibat adanya kerusakan jaringan. Secara tradisional daun $A$. muricata diyakini juga mampu meredakan rasa sakit. Pernyataan ini didukung oleh hasil penelitian yang menemukan bahwa pada dosis $600 \mathrm{mg} / \mathrm{kgBB}$ A. muricata memiliki efek analgesik tertinggi yaitu: 7,72 detik pada induksi jam ke-4 (Kuswinarti et al., 2018). Efek analgesik ini kemungkinan diperoleh melalui interaksinya pada jalur opioidergik dan sifat anti-inflamasi melalui penghambatan mediator kimia proinflamasi.

Pada uji in vitro, A. muricata mampu menujukkan efek penghambatan pada aktivitas siklooksigenase (COX)-1 dan COX-2 masingmasing sebesar $39,44 \% \pm 0,05 \%$ dan $55,71 \% \pm$ 0,12\%, pada dosis $100 \mu \mathrm{g} / \mathrm{mL}$ (Ishola et al., 2014). COX berperan aktif dalam proses inflamasi. Penghambatan pada COX menyebabkan tidak terbentuknya senyawa prostaglandin dan tromboksan. Karena senyawa ini adalah penyebab utama timbulnya rasa nyeri, akibatnya melalui pemberian ekstrak tanaman 
ini rasa nyeri akan dapat berkurang. Penelitian lain menemukan bahwa ekstrak A. muricata mampu menghambat inflamasi melalui penghambatan fosfolipase A2, menghambat kerja prostaglandin sintase dan stabilisasi membran. Stabilisasi membran adalah bagian dari mekanisme efek anti-inflamasi. Stabilisasi membran dapat mencegah kebocoran serum protein dan cairan ke dalam jaringan selama periode peningkatan permeabilitas pembuluh darah yang disebabkan oleh mediator inflamasi (Oyekachukwu et al., 2016).

\section{Efek Terhadap Tekanan Darah dan Asam}

Urat

Efek penurunan tekanan darah dilaporkan melalui beberapa hasil penelitian. Salah satu studi melaporkan, 9.17-48.5 mg/kg $A$. muricata menyebabkan penurunan tekanan darah yang bermakna tanpa mempengaruhi tingkat detak jantung. Efek hipotensif ini tidak dimediasi melalui jalur muskarinik, histaminergik, adrenergik, dan nitrit oksida, tetapi melalui mekanisme perifer yang melibatkan antagonisme $\mathrm{Ca}^{2+}$ (Nwokocha et al., 2012). A. muricata juga mampu menormalkan tekanan darah, mengurangi penanda stres oksidatif, dan menormalkan kadar nitrix oxide sehingga membantu menimbulkan vasodilatasi pembuluh darah. Hasil ini menunjukkan bahwa A. muricata memiliki aktivitas antihipertensi yang cukup menjanjikan sehingga layak untuk dilakukan pengujian lebih lanjut (Ola-Davies et al., 2019; Oridupa et al., 2018).

A. muricata juga dilaporkan mampu mengurangi kadar asam urat dalam serum pada kelompok kontrol setelah 12 minggu pengobatan (Alatas et al., 2019). A. muricata menunjukkan aktivitas antiurisemia yang baik pada tikus jantan dan betina. Persentase penurunan kadar asam tertinggi terjadi pada hari ke 8 pada tikus jantan yang diberi perlakuan $270 \mathrm{mg}$ granul sirsak dan pada hari ke 12 pada tikus betina yang mendapat $180 \mathrm{mg}$ granul sirsak. Secara keseluruhan hasil ini menunjukkan sirsak memiliki potensi sebagai antiurisemia alami (Djarot, 2018). Walaupun demikian, penelitian mengenai efek ini masih sangat terbatas, sehingga masih memerlukan pengujian secara menyeluruh sebelum digunakan pada manusia.

\section{Efek Antimikroba}

Efek sebagai antimikroba tanaman ini dilaporkan oleh beberapa penelitian. Salah satunya yaitu penelitian yang menilai ekstrak air tanaman ini dimana diketahui bersifat antibakteri terhadap $S$. aureus dan $V$. cholerae, walaupun pengujian dengan menggunakan 
ektrak etanol belum menunjukkan efek yang sama (Vieira et al., 2010). Ekstrak heksana $A$. muricata juga menunjukkan adanya kandungan beberapa metabolit, seperti tanin dan flavonoid. Semua zat ini terkait dengan aktivitas antimikroba dan menunjukkan penghambatan pertumbuhan terhadap bakteri dengan nilai minimum inhibition concentration $\geq 1024$ $\mu \mathrm{g} \cdot \mathrm{mL}^{-1}$. Ketika dikombinasikan dengan aminoglikosida, terjadi peningkatan aktivitas antibiotik yang baik, sehingga dapat menjadi sumber produk yang menjanjikan untuk mengendalikan bakteri (Bento et al., 2013), Studi lain juga menunjukkan bahwa buah $A$. Muricata yang difermentasi dan tidak difermentasi memiliki aktivitas antibakteri terhadap bakteri gram negatif dan gram positif, tetapi potensi lebih tinggi ditunjukkan oleh buah yang difermentasi (Otto et al., 2015). Berdasarkan data-data hasil penelitian ini tampaknya tanaman ini juga memiliki potensi sebagai antibakteri, walapun penelitian lebih lanjut masih diperlukan karena hingga saat ini pengujian masih terbatas pada penelitian secara in vitro dan in vivo.

\section{Uji Toksisitas dan Keamanan}

Hasil toksisitas oral akut dari ekstrak etanol dari daun $A$. muricata menemukan bahwa nilai median lethal dose $\left(\mathrm{LD}_{50}\right)$ ekstrak etanol adalah 3750 mg.kg-1 ${ }^{-1}$ yang tergolong dalam toksisitas kelas rendah (Gbaguidi et al., 2017). Studi lain melaporkan bahwa $\mathrm{LD}_{50}$ ekstraks daun A. muricata sebesar $1091.7 \mathrm{mg} / \mathrm{kg}$ dan menunjukkan adanya efek penekanan pada system saraf pusat akibat interaksinya pada sistem GABAergik dan monoaminergik (Souza et al., 2018).

Pemberian ekstrak ini juga tidak menimbulkan efek negatif pada hati, ginjal, jantung dan lambung. Parameter hematologis, alanine aminotransferase (ALT), aspartate transaminase (AST), alkaline phosphatase (ALP), urea dan albumin tidak terpengaruh, sedangkan kadar kreatinin meningkat pada dosis $2500 \mathrm{mg} / \mathrm{kg} / \mathrm{hari}$. Dengan demikian, ekstrak ini terbukti aman dan tidak menghasilkan efek toksik pada hewan pada dosis rendah dan sedang, tetapi dapat menyebabkan kerusakan ginjal yang mengarah pada gagal ginjal pada dosis yang lebih tinggi. Efek negatif juga dilaporkan pada fungsi uterus pada dosis tinggi. Peningkatan berat uterus mulai ditemukan pada dosis $1000 \mathrm{mg} / \mathrm{kg}$. Oleh karenannya, fungsi ginjal harus dimonitor dengan baik untuk pemakaian jangka panjang, serta harus dihindari selama kehamilan (Arthur et al., 2011). 
Namun, beberapa senyawa yang

diisolasi dari $A$. muricata menunjukkan efek neurotoksik baik secara in vitro dan in vivo (Coria-Téllez et al., 2018; Rady et al., 2018).

Ekstrak daging buah $A$. Muricata menunjukkan efek neurotoksik terkuat yaitu menyebabkan $67 \%$ kematian sel pada konsentrasi $1 \mu \mathrm{g} / \mathrm{mL}$. Hasil ini menunjukkan bahwa asupan suplemen makanan yang mengandung bahan nabati dari Annonaceae dapat berbahaya bagi kesehatan akibat efek neurotoksiknya (Höllerhage et al., 2015)

\section{SIMPULAN DAN SARAN}

A. muricata selama ini sudah banyak digunakan untuk pengobatan tradisional. Pemanfaatan sebagai antikanker, antibakteri, asam urat, pengontrol tekanan darah, mengurangi rasa nyeri, dan mengontrol kadar gula darah pada kondisi diabetes melitus tampaknya didukung oleh penelitian in vitro dan in vivo yang memadai. Dari semua efek tersebut, efek sebagai antikanker memiliki prospek yang paling menjanjikan. Apabila diuji dan diproduksi dengan benar $A$. muricata memilik berpotensi atau manfaat yang besar untuk mengembangan pengobatan karena mudah didapat dan terjangkau. Meskipun bebebarapa studi melaporkan bahwa konsumsi tidak selalu menyebabkan toksisitas akut, akan tetapi penelitian lebih lanjut masih diperlukan untuk mengidentifikasi dan mengukur kandungan senyawa fitokimia beracun serta menentukan dosis yang dapat menginduksi toksisitas pada manusia. Hal yang lebih penting adalah diperlukan lebih banyak penelitian yang menguji keamanan, dosis optimal, mekanisme aksi, dan profil toksisitas baik akut maupun kronis pada hewan sebelum digunakan secara luas pada manusia.

\section{DAFTAR PUSTAKA}

Agu, K.C., Eluehike, N., Ofeimun, R.O., Abile, D., Ideho, G., Ogedengbe, M.O., Onose, P.O., and Elekofehinti, O.O. 2019. Possible anti-diabetic potentials of Annona muricata (soursop): inhibition of $\alpha$-amylase and $\alpha$-glucosidase activities. Clinical Phytoscience. 5:21.

Alatas, H., Sja'bani, M., Mustofa, M. Mukti, A.G., Bawazier, L.A., Irijanto, F., Zulaela, Z and Tomino, Y. 2019. The effects of soursop supplementation on blood pressure, serum uric acid, and kidney function in a prehypertensive population in accordance with the 2017 ACC/AHA guideline. J Hum Hypertens. $34: 223-232$

Arthur, F.K.N., Woode, E., Terlabi, E.O., and Larbie, C. 2011. Evaluation of acute and subchronic toxicity of Annona Muricata (Linn.) aqueous extract in animals. Euro. J. Exp. Bio. 1(4):115-124.

Bento, H.B., Matias, E.F.F., Brito Jr, F.E., Oliveira, D.R., Coutinho, H., Costa, F.G.M., Kerntopf, M.R., and Menezes, I.R.A. 2013. Association Between Food and Drugs: Antimicrobial and Synergistic Activity of Annona muricata L. 
International Journal of Food Properties. 16(4): 738-744.

Coria-Téllez, A.V., Montalvo-Gónzalez, E., Yahia, E.M., and Obledo-Vázquez, E.N. 2018. Annona muricata: A comprehensive review on its traditional medicinal uses, phytochemicals, pharmacological activities, mechanisms of action and toxicity. Arabian Journal of Chemistry. 11(5): 662-691.

Dai, Y., Hogan, S., Schmelz, E.M., Ju, Y.H., Canning, C., and Zhou, K. 2011. Selective Growth Inhibition of Human Breast Cancer Cells by Graviola Fruit Extract In Vitro and In Vivo Involving Downregulation of EGFR Expression. Nutrition and Cancer. 63(5):795-801.

Deep, G., Kumar, R., Jain, A.K., Dhar, D., Panigrahi, G.K., Hussain, A., Chapla, A., El-Elimat, T., Ssica, V.P., Oberlies, N.H., and Agarwal, R. 2016. Graviola inhibits hypoxia-induced NADPH oxidase activity in prostate cancer cells reducing their proliferation and clonogenicity. Scientific Reports. 6(1):23135.

Djarot, P. 2018. Anti-hyperuricemicactivity of granule formulated from Anonna muricata L. fruit juice on hyperuricemia induce Sprague-Dawleys rat. International Journal of Herbal Medicine. 6(2): 121126.

Fatimah, S., Arisandi, D., dan Sismawati, S., 2019. Pengaruh pemberian ekstrak etanol buah sirsak (Anonna muricata L.) pada kadar kolesterol low density lipoprotein (LDL) tikus putih (rattus norvegicus) hiperkolesterolemia. Jurnal Biomedika. 12(2): 167-174.

Florence, N.T., Benoit, M.Z., Jonas, K., Alexandra, T., Désiré, D.D., Pierre, K., and Théophile, D. 2014. Antidiabetic and antioxidant effects of Annona muricata (Annonaceae), aqueous extract on streptozotocin-induced diabetic rats. $J$ Ethnopharmacol. 151(2):784-90.

Gavamukulya, Y., Abou-Elella, F., Wamunyokoli, F., and El-Shemy, $\mathrm{H}$. 2014. Phytochemical screening, anti- oxidant activity and in vitro anticancer potential of ethanolic and water leaves extracts of Annona muricata (Graviola). Asian Pac J Trop Med. 7(1):S355-S363.

Gavamukulya, Y., Wamunyokoli, F., and ElShemy, H.A. 2017. Annona muricata: Is the natural therapy to most disease conditions including cancer growing in our backyard? A systematic review of its research history and future prospects. Asian Pacific Journal of Tropical Medicine. 10(9): 835-848.

Gbaguidi, B.A., Anjou, E.S., Koutchiko, A., Dahouenon-Ahoussi, E., Sezan, A., and Dominique, S. 2017. Phytochemical and acute toxicity of ethanolic extract from leaves of Annona muricata (L.) from Benin in experimental albino rats. IJCS. 5(6): 39-4.

Höllerhage, M., Rösler, T.W., Berjas., M., Luo, R., Tran, K., Richards, K.M., Sabaa-Srur, A.U., Maia, J.G.S., de-Moraes, M.R., Godoy, H.T., Höglinger, G.U., and Smith, R.E. 2015. Neurotoxicity of dietary supplements fromAnnonaceaespecies. International Journal of Toxicology. 34(6):543-550.

Ishola, I.O., Awodele, O., Olusayero, A.M., and Ochieng, C.O. 2014. Mechanisms of analgesic and anti-inflammatory properties of Annona muricata Linn. (Annonaceae) fruit extract in rodents. $J$ Med Food. 17(12):1375-82.

Kuswinarti, K., Savira, K., and Rudiman, R. 2018. The Analgesic Effect of Ethanol Extract Soursop (Annona muricata L.) Leaves in Wistar Rats $A M J$. 5(4):196200.

Liaw, C.C., Liou, J.R., Wu, TY, Chang, F.R., and $\mathrm{Wu}, \mathrm{Y} . \mathrm{C} .2016$. Acetogenins from Annonaceae. Prog Chem Org Nat Prod. 101:113-230.

Moghadamtousi, S.Z., Fadaeinasab, M., Nikzad, S., Mohan, G., Ali, H.M., and Kadi, H.A. 2015. Annona muricata(Annonaceae): A Review of Its Traditional Uses, Isolated Acetogenins and Biological Activities. Int. J. Mol. Sci. 16:15625-15658. 
Moghadamtousi, S.Z., Kadir, H.A., Paydar, M., Rouhollahi, E., and Karimian, H. 2014. Annona muricataleaves induced apoptosis in A549 cells through mitochondrialmediated pathway and involvement of NF- $\mathrm{kB}$ BMC Complementary and Alternative Medicine. 14(1).

Nwokocha, C.R., Owu, D.U., Gordon, A., Thaxter, K., McCalla, G., Ozolua, R.I., and Young, L. 2012. Possible mechanisms of action of the hypotensive effect of Annona muricata (soursop) in normotensive Sprague-Dawley rats. Pharm Biol. 50(11):1436-41.

Ola-Davies, O.E., Oyagbemi, A.A., Omobowale, T.O., Akande, I., and Ashafa, A. 2019. Ameliorative effects of Annona muricata Linn. (Annonaceae) against potassium dichromate-induced hypertension in vivo: involvement of Kim-1/p38 MAPK/Nrf2 signaling. Journal of Basic and Clinical Physiology and Pharmacology. 30(4): doi:10.1515/jbcpp-2018-0172.

Oridupa, C.O.A., Falade, F.B., Oyagbemi, A.A., Abegunde, B.A., Ekwem, P.C., Badmus A., and Omobowale, T.O. 2018. Annona muricata Linn leaves or Curcuma longa Linn Rhizomes Ameliorates Oxidative Stress Associated with Hypertension in Uninephrectomized Wistar Rats Daily Loaded with Sodium. EJMP. 26(4): 1-13.

Otto, R.B.D., Nankwanga, M., and Sesaazi, D. 2015. Comparison of Antibacterial Activities of Fermented with those of Unfermented Annona muricata (L) Fruit Extracts. Int. J. Curr. Microbiol. App. Sci. 4(6): 696-707.

Oyekachukwu, A.R., Elijah, J.P., Eshu, O.V., and Nwodo, O.F.C. 2016. AntiInflammatory Effects of The Chloroform Extract of Annona muricata Leaves on Phospholipase A2 and Prostaglandin Synthase Activities. Transl Biomed. 8(4):137.

Rady, I., Bloch, M.B., Chamcheu, R.N., Mbeumi, S.B., Anwar, M.R., Mohamed, H., Babatunde, A.S., Kuiate, J.R., Noubissi, F.K., El Sayed, K. A.,
Whitfield, G.K., and Chamcheu, J.C.. 2018. Anticancer Properties of Graviola (Annona muricata): A Comprehensive Mechanistic Review. Oxidative Medicine and Cellular Longevity. 1826170.

Roduan, M.R.M., Hamid, R.A., Cheah, Y.K., and Mohtarrudin, N. 2019. Cytotoxicity, antitumor-promoting and antioxidant activities of Annona muricata in vitro. Journal of Herbal Medicine. 15:100219.

Sasso, S., Sampaio E Souza, P.C., Santana, L.F., Cardoso, C.A.L., Alves, F.M., Portugal, L.C., de Faria, B.B., da Silva, A.F., Motta-Castro, A.R.C., Soares, L.S., Bandeira, L.M., Guimarães R.d.A., and Freitas, K.d.C. 2019. Use of an Extract of Annona muricata Linn to Prevent High-Fat Diet Induced Metabolic Disorders in C57BL/6 Mice. Nutrients. 1(7):1509.

Souza, D.O., Dos Santos Sales V., de Souza Rodrigues C.K., de Oliveira, L.R., Lemos, I.C.S., Delmondes, G.d.A., Monteiro, A.B., do Nascimento, E.P., de Figuêiredo, F.R.S.D.N., da Costa, J.G.M., da Cruz, G.M.P., Viana, G.S.d.B., Barbosa, R., de Menezes, I.R.A., Felipe, C.F.B., and Kerntopf, M.R. 2018. Phytochemical Analysis and Central Effects of Annona Muricata Linnaeus: Possible Involvement of the Gabaergic and Monoaminergic Systems. Iran J Pharm Res.17(4):13061317.

Torres, M.P., Rachagani, S., Purohit, V., Pandey, P., Joshi, S., Moore, E.D., Johansson, S.L., Singh, P.K., Ganti, A.K., and Batra, S.K. 2012. Graviola: a novel promising natural-derived drug that inhibits tumorigenicity and metastasis of pancreatic cancer cells in vitro and in vivo through altering cell metabolism. Cancer Lett. 323(1):29-40.

Vieira, G.H.F., Mourão, J.A., Ângelo, A.M., Costa, R.A., and Vieira, R.H.S.F. 2010. Antibacterial effect (in vitro) of moringa oleifera and annona muricata against gram positive and gram negative bacteria. Rev. Inst. Med. Trop. Sao Paulo. 52(3):129-132. 